\title{
Antioxidants and Oxidative Stress in BAL Fluid of Atopic Asthmatic Children
}

\author{
BETTINA C. SCHOCK, IAN S. YOUNG, VANESSA BROWN, PATRICK S. FITCH, \\ MICHAEL D. SHIELDS, AND MADELEINE ENNIS \\ Departments of Clinical Biochemistry [B.C.S., I.S.Y., V.B., P.S.F., M.E.] and Child Health [P.S.F., \\ M.D.S.], The Queen's University of Belfast, Belfast BT12 6BJ, Northern Ireland, U.K.
}

\begin{abstract}
Earlier studies in adults have indicated that increased oxidative stress may occur in the blood and airways of asthmatic subjects. Therefore the aim of this study was to compare the concentrations of antioxidants and protein carbonyls in bronchoalveolar lavage fluid of clinically stable atopic asthmatic children (AA, $n=78$ ) with our recently published reference intervals for nonasthmatic children (C, $n=124)$. Additionally, lipid peroxidation products (malondialdehyde) in bronchoalveolar lavage fluid and several antioxidants in plasma were determined. Bronchoalveolar lavage concentrations (median and interquartile range) of ascorbate [AA: $0.433(0.294-0.678)$ versus C: $0.418(0.253-0.646) \mu \mathrm{mol} / \mathrm{L}]$, urate [AA: $0.585(0.412-$ $0.996)$ versus $\mathrm{C}: 0.511(0.372-0.687) \mu \mathrm{mol} / \mathrm{L}], \alpha$-tocopherol [AA: 0.025 (0.014-0.031) versus C: 0.017 (0.017-0.260) $\mu \mathrm{mol} /$ L], and oxidized proteins as reflected by protein carbonyls [AA: $1.222(0.970-1.635)$ versus $\mathrm{C}: 1.243(0.813-1.685) \mathrm{nmol} / \mathrm{mg}$ protein] were similar in both groups ( $p>0.05$ in all cases). The
\end{abstract}

\section{ABSTRACT}

concentration of protein carbonyls correlated significantly with the number of eosinophils, mast cells, and macrophages in AA children only. Concentrations of oxidized proteins and lipid peroxidation products (malondialdehyde) correlated significantly in AA children $(r=0.614, n=11, p=0.044)$. Serum concentrations of ascorbate, urate, retinol, $\alpha$-tocopherol, $\beta$-carotene, and lycopene were similar in both groups whereas $\alpha$-carotene was significantly reduced in asthmatics. Overall, increased bronchoalveolar lavage eosinophils indicate ongoing airway inflammation, which may increase oxidatively modified proteins as reflected by increased protein carbonyl concentrations. (Pediatr Res 53: 375-381, 2003)

Abbreviations
BAL, bronchoalveolar lavage
ICS, inhaled corticosteroid
MDA, malondialdehyde

The epithelial lining fluid of the lung with its high concentration of antioxidants provides a first line of defense against inhaled, but also endogenously produced, oxidants $(1,2)$. Epidemiologic studies have found an inverse association between ascorbate intake and bronchial hyperresponsivness (3). In a small group of patients with exercise-induced asthma, Cohen et al. (4) showed that supplementation with ascorbate improved lung function. Dietary supplementation with a vitamin combination (ascorbic acid, $\alpha$-tocopherol, and $\alpha$-carotene) also had some positive effect on lung function during exercise in combination with ozone exposure (5). Studies in adults living in the United Kingdom have shown that low intake of fresh fruit and vegetables is a risk factor for decreased lung function $(6,7)$. Changes in ascorbate and urate in the lining

Received May 8, 2001; accepted March 8, 2002.

Correspondence: Madeleine Ennis, Ph.D., Department Clinical Biochemistry, Institute of Clinical Science, The Queen's University of Belfast, Grosvenor Road, Belfast BT12 6BJ, U.K.; e-mail: m.ennis@qub.ac.uk

Supported by grants from the National Asthma Campaign, U.K., Northern Ireland Mother and Baby Appeal, and the Deutscher Akademischer Austauschdienst (DAAD), Germany.

DOI: 10.1203/01.PDR.0000049625.51462.D1 fluid of the respiratory tract have been observed as a response to acute air pollution exposure (8) and recently in adults with mild asthma (9). Inflammatory cells from peripheral blood and BAL fluid of asthmatic subjects produce more superoxide anion radicals than those of control subjects (10-12). Treatment with corticosteroids has been shown to reduce the amount of oxygen radicals released by these cells (13).

In children, asthma is defined by symptoms such as wheeze or cough (14), and we have recently shown that atopic asthma is a chronic inflammatory disease in children as in adults (15). Ongoing inflammation in the airways of children with atopic asthma may lead to enhanced oxidative stress in the epithelial lining fluid, which may, as a consequence, lead to a higher consumption of the antioxidants found in BAL fluid. Oxidative damage to BAL proteins may reflect overall oxidative stress to the respiratory tract that could contribute to the underlying pathophysiology of established asthma. We have recently reported concentrations of total ascorbate, urate, $\alpha$-tocopherol, and oxidized proteins in BAL fluid in nonasthmatic children (16). However, there are currently no data available on the antioxidant status in the epithelial lining fluid of asthmatic 
children. The present study compares the concentrations of those antioxidants and oxidized proteins in BAL fluid of children with stable atopic asthma with our normal values. Additionally, we determined MDA as a marker of lipid peroxidation in BAL fluid and several antioxidants in serum of these children.

\section{METHODS}

Subjects. Otherwise well, stable, atopic asthmatic children attending the Royal Belfast Hospital for Sick Children for elective surgery for a noninflammatory condition were recruited as part of an ongoing research study on childhood asthma. A detailed respiratory and allergy history, which also included information on parental smoking, type of home heating, and serum IgE measurements, was used, as previously described, to categorize the children $(17,18)$. The children were defined as atopic asthmatics because in addition to recurrent episodes of wheezing they had some or all of the following features: 1) other atopy (eczema, hayfever), 2) wheeze triggered by aeroallergen exposure, or 3) an elevated serum IgE ( $>2$ SD from age normal controls) (17). Forty-seven children were reported to take antiinflammatory asthma therapy (43 ICS, four sodium cromoglycate). A further 18 children used bronchodilators only when required. We compared the results from the atopic asthmatic children $(n=78)$ with a group of 124 control children (nonasthmatic-nonatopic and atopicnonasthmatic) whom we have previously reported (16). All children (atopic asthmatic and nonasthmatic) were attending elective surgery for a noninflammatory condition, mainly for minor corrective plastic surgery, surgery to the renal tract, and repairs of cleft lips and palate. At the time of the investigation all children were considered to be free from recent upper respiratory tract infections for at least $2 \mathrm{wk}$. Additionally none of the parents or guardians reported asthma exacerbations experienced by the children at the time of the study, and all were deemed fit for surgery by the anesthetist. Written informed consent was obtained from parents or guardians of each recruited subject before surgery. The study was approved by the Research Ethics Committee of The Queen's University of Belfast.

Bronchoalveolar lavage. BAL procedure followed our standard protocol for a blind nonbronchoscopic technique $(16,18)$. Briefly, after the induction of anesthesia and intubation, a sterile $8 \mathrm{~F}$ graduated neonatal suction catheter was inserted through the endotracheal tube and wedged in a distal airway. Lavage was performed with a single $20-\mathrm{mL}$ aliquot of normal saline, and the lavage fluid was immediately aspirated. A $500-\mu \mathrm{L}$ aliquot of the sample was incubated with a final concentration of $10 \mathrm{mmol} / \mathrm{L} \mathrm{Na}{ }_{2} E D T A$ and $35 \mathrm{mmol} / \mathrm{L}$ DTT for $30 \mathrm{~min}$ on ice and in the dark. After centrifugation $(200 \times$ $g, 5 \mathrm{~min}, 4^{\circ} \mathrm{C}$ ) the supernatant was frozen at $-70^{\circ} \mathrm{C}$ until assayed.

Total cell count and differential cell counts. Cells in BAL fluid were enumerated as previously described (18). Briefly, after total cell count using a Neubauer chamber, coverslip preparations were prepared and stained with a commercially available stain (DiffQuick, Baxter AG, Düdingen, Switzer- land), and a total number of at least 500 cells were counted and differentiated in a blinded fashion. Mast cells were enumerated after fixation in Carnoy's solution and staining with toluidine blue, with 2000-5000 cells counted per coverslip.

Ascorbic acid and uric acid in BAL fluid. The HPLC method with electrochemical detection described by Chevion et al. (19) was used to determine ascorbate and urate concentrations. Standards of both antioxidants $(0.25-2 \mu \mathrm{mol} / \mathrm{L})$ were prepared in $0.9 \%$ sodium chloride with a final concentration of $10 \mathrm{mmol} / \mathrm{L} \mathrm{Na} \mathrm{Na}_{2}$ TA and $35 \mathrm{mmol} / \mathrm{L}$ DTT. The detection limits were $0.106 \mu \mathrm{mol} / \mathrm{L}$ for ascorbate and $0.030 \mu \mathrm{mol} / \mathrm{L}$ for urate. The interassay coefficient of variation was $7.8 \%$ for ascorbic acid $(n=33)$ and $9.1 \%(n=28)$ for uric acid.

$\boldsymbol{\alpha}$-Tocopherol in BAL fluid. $\alpha$-Tocopherol was measured by HPLC with electrochemical detection according to the method described by Ikenoya et al. (20). Extraction of $\alpha$-tocopherol was performed as described by Ito et al. (21). The detection limit was $0.0028 \mu \mathrm{mol} / \mathrm{L}(n=5)$, and the interassay coefficient of variation was $12.1 \%(n=24)$.

Protein carbonyls in BAL fluid. Carbonyl concentrations were determined using an in-house ELISA as described by Buss et al. (22). Briefly, after derivatization of carbonyl groups with dinitrophenylhydrazine (DNPH), proteins were adsorbed onto 96-well ELISA plates, captured with a commercially available anti-DNPH antibody, and detected with a horseradish peroxidase-hydrogen peroxide, phenylene diamine system (18). The limit of detection was $0.28 \mathrm{nmol} / \mathrm{mg}$ protein.

Total protein. Total protein concentrations were quantified using the commercially available Bio-Rad assay (Bio-Rad Laboratories Ltd., Hemel Hempstead, U.K.).

MDA assay. MDA was determined by HPLC with fluorometric detection after reaction with thiobarbituric acid (23). The limit of detection was $0.03 \mu \mathrm{mol} / \mathrm{L}$.

Antioxidants in serum. The lipid-soluble vitamins retinol, $\alpha$-tocopherol, $\alpha$-carotene, $\beta$-carotene, and lycopene were measured by HPLC with UV detection as described by Ito et al. (21). Ascorbate and urate were determined in serum samples after deproteination in 5\% $m$-phosphoric acid (19). The detection limits were $0.11 \mu \mathrm{mol} / \mathrm{L}$ for retinol, $1.2 \mu \mathrm{mol} / \mathrm{L}$ for $\alpha$-tocopherol, $0.01 \mu \mathrm{mol} / \mathrm{L}$ for carotenoids, $6.2 \mu \mathrm{mol} / \mathrm{L}$ for ascorbate, and $12.3 \mu \mathrm{mol} / \mathrm{L}$ for urate.

Data analyses. The data were described using mean $\pm \mathrm{SD}$ or median (interquartile range, IQR) as appropriate. Statistical comparisons were performed using the Mann-Whitney $U$ test. The Spearman's correlation coefficient was used to calculate the association between variables. A probability value of $<0.05$ was regarded as statistically significant. All statistical analyses were carried out using SPSS (Version 8.0, Chicago, IL, U.S.A.) for Windows and GraphPad Prism (Version 2.01, San Diego, CA, U.S.A.).

\section{RESULTS}

Subjects. A total of 78 atopic, asthmatic children [AA: mean age, $7.2 \pm 3.3$ y; range, 1.1-13.5 y; 49 boys] were studied. One hundred twenty-four healthy nonasthmatic children of a similar age were used as controls, as previously reported (16) (Table $1)$. 
Table 1. Characteristics of all children studied

\begin{tabular}{lcc}
\hline & Atopic asthmatics & Controls \\
\hline Number & 78 & $124 \dagger$ \\
Mean age in years & $7.2(3.3)$ & $7.1(2.8)$ \\
$\quad$ (SD) & $(1.1-13.5)$ & $(1.6-12.6) \dagger$ \\
(min - max) & $49 / 29$ & $68 / 56 \dagger$ \\
Male/Female & $67(7.0-174.0)^{*}$ & $13.5(5.0-37.8)$ \\
Total IgE (kU/L) & $(2.00-1001.0)$ & $(1.99-107.0)$ \\
(min - max) & $46 / 76(59 \%)$ & $68 / 122(56.7 \%) \dagger$ \\
Exposure to parental & & $0.80(0.55-1.08)$ \\
ETS (of total) & & $80.3(68.47-94.1)$ \\
BAL & $0.97(0.63-0.97)$ & $6.72(1.92-7.70)$ \\
Total cells (×105/mL) & $75.2(62.1-92.3)$ & $1.57(0.38-1.96)$ \\
Macrophages (\%) & $10.3(1.5-12.77)$ & $0.58(0.0-0.38)$ \\
Neutrophils (\%) & $1.38(0.23-1.94)$ & $0.07(0.0-0.08)$ \\
Lymphocytes (\%) & $1.76(0.19-1.49)^{*}$ & $10.85(0.66-16.54)$ \\
Eosinophils (\%) & $0.19(0.02-0.29)^{*}$ & \\
Mast cells (\%) & $11.46(0.96-16.10)$ & \\
Epithelial cells (\%) & & \\
\hline
\end{tabular}

Characteristics of all atopic asthmatic children studied. For comparison the characteristics of previously published controls are given (16). The two subgroups did not differ significantly from each other in age $(p=0.78)$ or proportion to environmental tobacco smoke (ETS) exposure $\left(\chi^{2}=0.27, p>0.05\right)$. Total IgE and BAL cells, data shown as mean (IQR).

$* p<0.001$. Data were not available for two children in each group for ETS exposure.

$\dagger$ Data previously reported in reference 16 .

The mean volume return was $36.5 \pm 12.7 \%$ in atopic asthmatic children and $36.8 \pm 11.8 \%$ in control children $(p=$ 0.99 ). The total and differential cell counts (mean percentage) are expressed in Table 1. The proportions of eosinophils and mast cells were significantly elevated in BAL fluid of atopic asthmatic children ( $p<0.0001$ and $p=0.0007$, respectively).

Antioxidants and oxidation products in BAL fluid. The concentrations of total protein [median (IQR)] were similar in atopic asthmatic children and controls (AA: $56.2(29.9-85.2)$ $\mu \mathrm{g} / \mathrm{mL}$, and C: $50.2(31.2-76.2) \mu \mathrm{g} / \mathrm{mL} ; p=0.47)$. Concentrations of antioxidants (ascorbate, urate, and $\alpha$-tocopherol, in $\mu \mathrm{mol} / \mathrm{L}$ ), total proteins (in $\mu \mathrm{g} / \mathrm{mL}$ ), and protein carbonyls (expressed in $\mathrm{nmol} / \mathrm{mg}$ and $\mathrm{pmol} / \mathrm{L}$ ) for asthmatics and controls are given in Table 2. The concentrations of total ascorbate (Fig. 1), urate (Fig. 2), and $\alpha$-tocopherol (Fig. 3; all in $\mu \mathrm{mol} / \mathrm{L}$ ) were similar in asthmatic children compared with the control group (all $p>0.05$ ). When corrected for total protein, median concentrations of total ascorbate and urate (in $\mathrm{nmol} / \mathrm{mg}$ protein) were lower in atopic asthmatic children compared with controls, but these differences were not statistically significant [ascorbate: $6.473(5.01-13.17) \mathrm{nmol} / \mathrm{mg}$ protein versus 8.720 $(5.569-15.41) \mathrm{nmol} / \mathrm{mg}$ protein, $p=0.15$; urate: 8.796
$(6.279-13.48) \mathrm{nmol} / \mathrm{mg}$ protein versus $9.578(7.205-15.63)$ $\mathrm{nmol} / \mathrm{mg}$ protein; $p=0.34]$. Similar concentrations between the two groups were found when $\alpha$-tocopherol was corrected for protein concentrations [AA: $0.367(0.173-0.602) \mathrm{nmol} / \mathrm{mg}$ versus $\mathrm{C}$ : $0.333(0.233-0.602) \mathrm{nmol} / \mathrm{mg} ; p=0.88$ for atopic asthmatic and control children, respectively].

The concentrations of protein carbonyls in BAL fluid (in $\mathrm{nmol} / \mathrm{mg}$ ) were similar in atopic asthmatic children and controls (Fig. 4 and Table 2). Corrected for the BAL volume, atopic asthmatics had a tendency for increased concentrations of protein carbonyls (in pmol/L) compared with controls, but this was not statistically significant [AA: $84.91(44.13-121.5)$ $\mathrm{pmol} / \mathrm{L}$ versus $67.37(39.48-114.8) \mathrm{pmol} / \mathrm{L}, p=0.30]$. In a small subgroup of the children, in whom we had adequate volume of lavage fluid, we measured MDA, a marker of lipid peroxidation. BAL fluid concentrations of MDA were also similar in atopic asthmatic children and nonasthmatic controls (Table 2).

Serum antioxidant concentrations. Serum concentrations of ascorbate, urate, $\alpha$-tocopherol, retinol, lycopene, and $\beta$-carotene were similar in the two groups of children. Children with atopic asthma had statistically significantly reduced serum

Table 2. Concentrations of antioxidants and markers of oxidative stress in BAL fluid

\begin{tabular}{lccl}
\hline & Atopic asthmatics & Controls & $p$ value \\
\hline Total protein $(\mu \mathrm{g} / \mathrm{mL})$ & $56.2(29.8-85.1)$ & $50.2(31.2-76.2)$ & 0.47 \\
Ascorbate $(\mu \mathrm{mol} / \mathrm{L})$ & $0.433(0.294-0.678)$ & $0.418(0.253-0.646)^{*}$ & 0.61 \\
Urate $(\mu \mathrm{mol} / \mathrm{L})$ & $0.585(0.412-0.996)$ & $0.511(0.372-0.687)^{*}$ & 0.09 \\
$\alpha$-Tocopherol $(\mu \mathrm{mol} / \mathrm{L})$ & $0.025(0.014-0.031)$ & $0.017(0.017-0.26)^{*}$ & 0.11 \\
Protein carbonyls $(\mathrm{nmol} / \mathrm{mg})$ & $1.22(0.97-1.64)$ & $1.24(0.813-1.69)^{*}$ & 0.75 \\
$\quad(\mathrm{pmol} / \mathrm{L})$ & $84.90(44.13-121.5)$ & $67.37(39.48-114.8)^{*}$ & 0.30 \\
MDA $(\mu \mathrm{mol} / \mathrm{L})$ & $0.09(0.04-0.12)$ & $0.08(0.04-0.12)$ & 0.88
\end{tabular}

Concentrations of antioxidants and markers of oxidative stress in BAL fluid of children with atopic asthma and nonasthmatic control children. Comparisons were made using Mann-Whitney $U$ test.

No statistically significant difference was found between the two groups.

* Data previously reported in reference 16. 


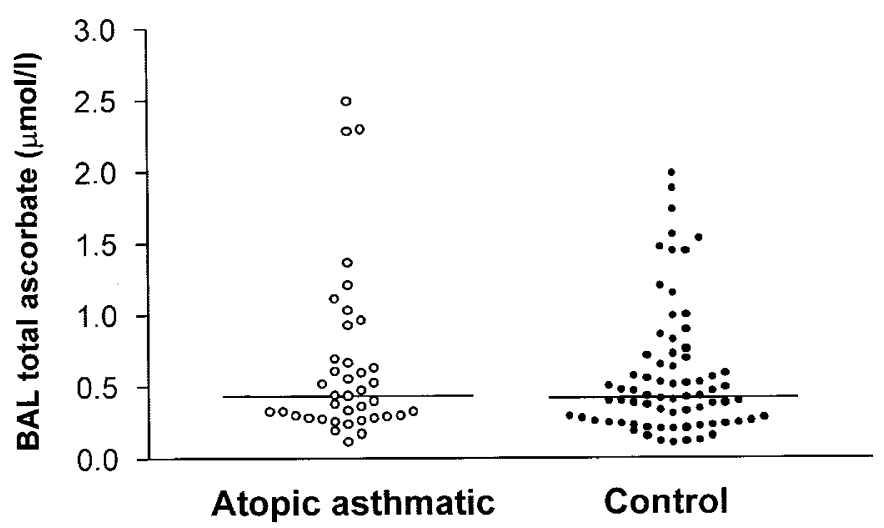

Figure 1. Concentrations of total ascorbate $(\mu \mathrm{mol} / \mathrm{L})$ in BAL fluid of children with atopic asthma (O). For comparison the concentrations for previously published control children (๑) are also plotted (16).

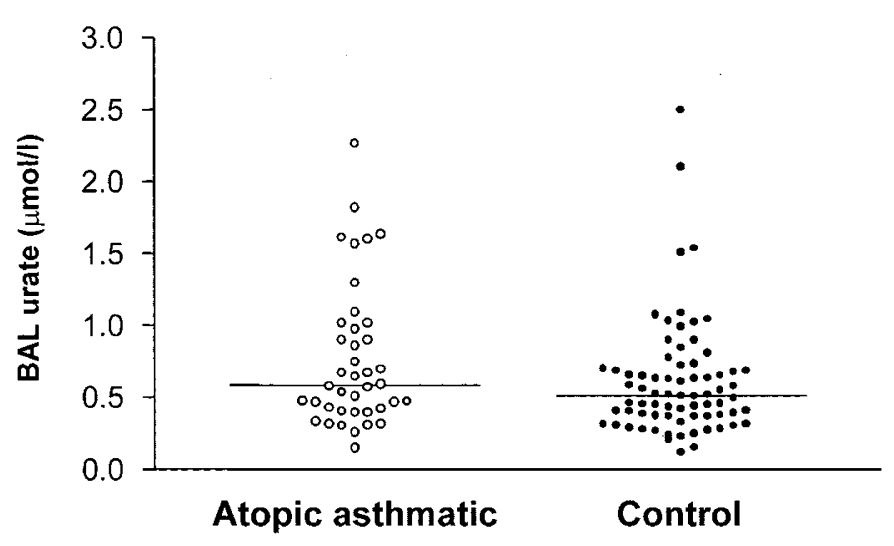

Figure 2. Concentrations of urate $(\mu \mathrm{mol} / \mathrm{L})$ in BAL fluid of children with atopic asthma (O). For comparison the concentrations for previously published control children $(\bullet)$ are also plotted (16).

concentrations of $\alpha$-carotene ( $p=0.048)$. The concentrations of serum antioxidants are given in Table 3 .

Correlations. We expressed the concentration of protein carbonyl residues in picomoles per liter to be able to analyze their association with antioxidant concentrations or numbers of inflammatory cells. In atopic asthmatic children the concentration of total protein correlated significantly with concentrations of all antioxidants measured in BAL fluid (ascorbate: $r=0.55$, $n=39, p=0.0003$; urate: $r=0.66, n=40, p<0.0001$; $\alpha$-tocopherol: $r=0.45, n=34, p=0.008$; Table 4). Correlations between oxidized proteins and ascorbate or urate were

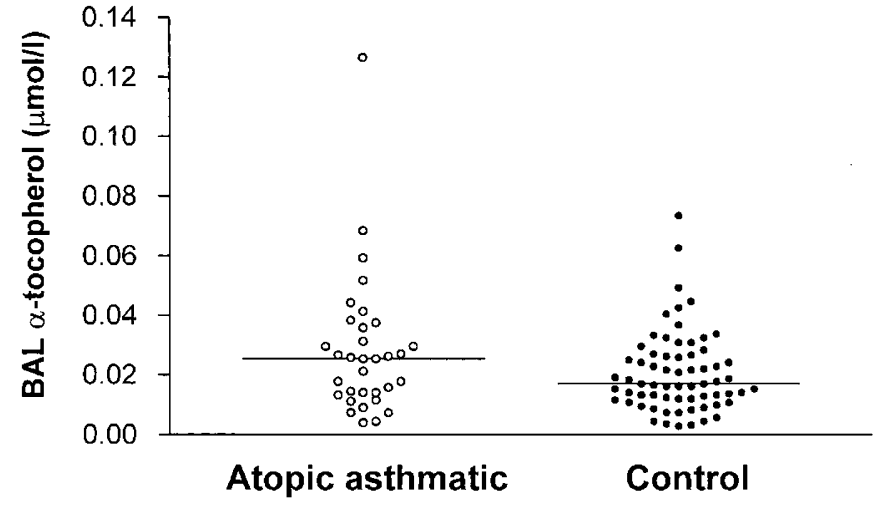

Figure 3. Concentrations of $\alpha$-tocopherol ( $\mu \mathrm{mol} / \mathrm{L}$ ) in BAL fluid of children with atopic asthma $(O)$. For comparison the concentrations for previously published control children $(\bullet)$ are also plotted (16).

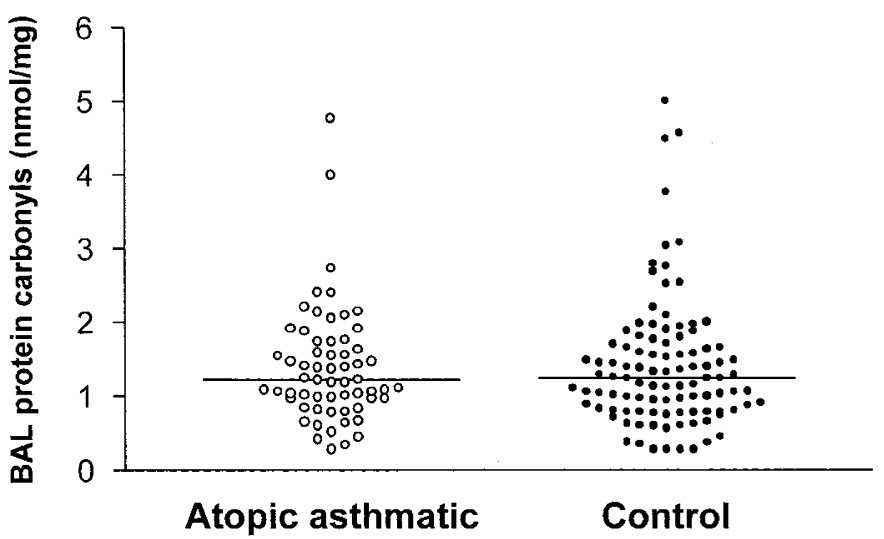

Figure 4. Protein carbonyl concentrations (nmol/mg protein) in BAL fluid of children with atopic asthma (O). For comparison the concentrations for previously published control children () are also plotted (16).

slightly higher for atopic, asthmatic children than nonasthmatic control children. In asthmatic children, the number of inflammatory cells $\left(\times 10^{5} / \mathrm{mL}\right)$ in BAL fluid correlated significantly with the concentration of protein carbonyls (all $p<0.05$; Table 4). Furthermore, in asthmatic children with BAL eosinophils, which were greater than our previously published upper $95 \%$ confidence limit of the 95th centile of our normal population (24) $\left(\geq 0.86 \%\right.$ or $\left.\geq 0.039 \times 10^{5} / \mathrm{mL}, n=30\right)$, protein carbonyls were significantly higher than in those asthmatic children with normal eosinophil numbers (elevated eosinophils: 107.5 $\mathrm{pmol} / \mathrm{L}$ versus normal eosinophils: $66.43 \mathrm{pmol} / \mathrm{L}, p<0.0028$ ). Thus ongoing airway inflammation is reflected by increased

Table 3. Water-soluble and lipid-soluble antioxidants in serum

\begin{tabular}{lccc}
\hline & Atopic asthmatic & Controls & $p$ value \\
\hline Ascorbate $(\mu \mathrm{mol} / \mathrm{L})$ & $75.88(56.37-92.75)$ & $75.66^{*}(62.37-99.30)$ & 0.78 \\
Urate $(\mu \mathrm{mol} / \mathrm{L})$ & $280.3(244.7-309.6)$ & $283.9^{*}(253.5-324.5)$ & 0.70 \\
$\alpha$-Tocopherol $(\mu \mathrm{mol} / \mathrm{L})$ & $17.78(14.86-20.96)$ & $17.96^{*}(15.21-22.03)$ & $0.807^{*}(0.676-0.964)$ \\
Retinol $(\mu \mathrm{mol} / \mathrm{L})$ & $0.789(0.672-1.04)$ & $0.033^{*}(0.019-0.055)$ & 0.82 \\
$\alpha$-Carotene $(\mu \mathrm{mol} / \mathrm{L})$ & $0.023(0.114-0.045)$ & $0.274 *(0.150-0.457)$ & 0.048 \\
$\beta$-Carotene $(\mu \mathrm{mol} / \mathrm{L})$ & $0.217(0.132-0.390)$ & $0.156^{*}(0.097-0.355)$ & 0.17 \\
Lycopene $(\mu \mathrm{mol} / \mathrm{L})$ & $0.146(0.057-0.329)$ & 0.33 & \\
\hline
\end{tabular}

Water-soluble and lipid-soluble antioxidants in serum. Controls: ascorbate $n=64$, urate $n=60$, all others $n=112$. Atopic asthmatic children: ascorbate/urate $n=38$, all others $n=72$. Results are given as median (IQR). Statistical comparisons between both groups were made using the Mann- Whitney $U$ test.

* Data previously reported in reference 16 . 
Table 4. Association between protein carbonyl concentrations and BAL fluid measurements

\begin{tabular}{|c|c|c|c|c|c|c|}
\hline & \multicolumn{3}{|c|}{ Atopic asthmatic } & \multicolumn{3}{|c|}{ Controls } \\
\hline \multicolumn{7}{|l|}{ BAL antioxidants } \\
\hline Ascorbate $(\mu \mathrm{mol} / \mathrm{mg})$ & 33 & 0.238 & 0.18 & 64 & -0.043 & 0.73 \\
\hline Urate $(\mu \mathrm{mol} / \mathrm{L})$ & 34 & 0.542 & 0.001 & 64 & 0.342 & $0.006^{*}$ \\
\hline Urate $(\mu \mathrm{mol} / \mathrm{mg})$ & 34 & 0.371 & 0.031 & 64 & -0.221 & 0.08 \\
\hline \multicolumn{7}{|l|}{ BAL cells } \\
\hline Macrophages $\left(\times 10^{5} / \mathrm{mL}\right)$ & 58 & 0.342 & 0.009 & 99 & 0.122 & 0.23 \\
\hline Macrophages (\%) & 58 & -0.450 & 0.0004 & 99 & -0.157 & 0.12 \\
\hline Neutrophils $\left(\times 10^{5} / \mathrm{mL}\right)$ & 58 & 0.407 & 0.0015 & 99 & 0.316 & 0.0014 \\
\hline Neutrophils (\%) & 58 & 0.154 & 0.25 & 99 & 0.145 & 0.15 \\
\hline Lymphocytes $\left(\times 10^{5} / \mathrm{mL}\right)$ & 58 & 0.508 & $<0.0001$ & 99 & 0.212 & 0.035 \\
\hline Mast cells (\%) & 57 & 0.479 & 0.0002 & 85 & 0.191 & 0.078 \\
\hline Epithelial cells $\left(\times 10^{5} / \mathrm{mL}\right)$ & 58 & 0.300 & 0.022 & 99 & 0.409 & $<0.0001$ \\
\hline Epithelial cells (\%) & 58 & 0.406 & 0.0016 & 99 & 0.142 & 0.16 \\
\hline
\end{tabular}

Association between protein carbonyls (nmol/L) and concentrations of BAL fluid ascorbate, urate, and $\alpha$-tocopherol (all $\mu \mathrm{mol} / \mathrm{L}$ ) and the number of BAL cells in atopic asthmatic and control children. Association between protein carbonyls (nmol/mg protein) and concentrations of BAL fluid ascorbate, urate, and $\alpha$-tocopherol (all $\mu \mathrm{mol} / \mathrm{mg}$ protein) and the percentage BAL cells in atopic asthmatic and control children. Statistical correlations ( $r$ ) were performed using the Spearman's correlation coefficient.

* Data previously reported in reference 16 .

oxidative damage to proteins. Additionally, in control children the numbers of eosinophils, mast cells, and macrophages did not correlate significantly with the concentrations of protein carbonyls (Table 4).

Furthermore, the concentrations of carbonyl residues showed a significant association with concentrations of MDA in atopic asthmatic children $(r=0.61, n=11, p=0.044)$ but not in control children ( $r=0.50, n=11, p=0.12$; Fig. 5).

There is concern that the concentrations of carbonyl residues may increase with the increase in total protein during inflammation. However, in atopic asthmatic children the concentration of protein carbonyls (in $\mathrm{nmol} / \mathrm{mg}$ ) did not correlate significantly with total protein (in $\mathrm{mg} / \mathrm{L} ; r=0.006, p=0.96, n$ $=61)$. Although some of the significant correlations between antioxidants (in $\mu \mathrm{mol} / \mathrm{mg}$ protein) and carbonyls (in $\mathrm{nmol} / \mathrm{mg}$ ) in lavage fluid disappeared, oxidized proteins were still significantly correlated with the numbers of inflammatory cells (Table 4).

In atopic asthmatic children there was no significant correlation between the concentrations of antioxidants in BAL fluid and their serum concentration. The correlation coefficients were for ascorbate, $r=-0.04, p=0.81, n=37$; for urate, $r$ $=0.13, p=0.42, n=38$; and for $\alpha$-tocopherol, $r=-0.10$, $p=0.59, n=28)$.

There were no statistically significant differences found in concentrations of total protein, antioxidants, and protein carbonyls for atopic, asthmatic children taking ICS, $\beta_{2}$-adrenergic agonists alone, or no treatment ( $p>0.05$ for each comparison; data not shown).

\section{DISCUSSION}

Earlier studies in adults have indicated that increased oxidative stress may occur in the circulation and airways of asthmatic subjects $(10-12)$. The epithelial lining fluid of the lung contains high concentration of antioxidants, which provide a first line of defense against inhaled, but also endogenously produced, oxidants $(1,2)$. A change in the antioxidant-

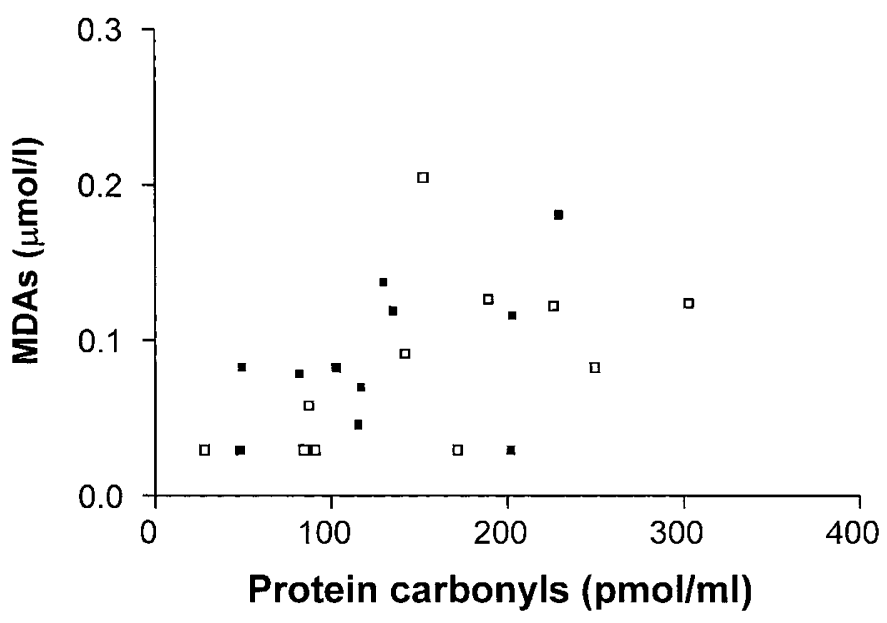

Figure 5. Association between the concentration of protein carbonyls $(\mathrm{nmol} / \mathrm{L})$ and lipid peroxidation products (measured as MDAs; $\mu \mathrm{mol} / \mathrm{L}$ ) in BAL fluid of atopic, asthmatic children $(\square ; r=0.614, p=0.044, n=11)$ and nonasthmatic control children $(\square ; r=0.50, p=0.12, n=11)$. Statistical correlations were performed using the Spearman's correlation coefficient. A $p$ value of $<0.05$ was considered statistically significant. 
oxidant balance in BAL fluid in children with asthma may be an indicator of ongoing inflammation even in symptom-free periods. Therefore, the aim of this study was to compare the concentrations of antioxidants and protein carbonyls in BAL fluid of atopic asthmatic children with recently published reference intervals for nonasthmatic children (16).

We found a wide range of all antioxidant concentrations in BAL fluid ranging from 0.106 to $1.985 \mu \mathrm{mol} / \mathrm{L}$ for ascorbate, from 0.120 to $2.498 \mu \mathrm{mol} / \mathrm{L}$ for urate, from 0.003 to 0.126 $\mu \mathrm{mol} / \mathrm{L}$ for $\alpha$-tocopherol, and from 0.208 to $5.011 \mathrm{nmol} / \mathrm{mg}$ for carbonyl residues in proteins, and these did not differ between stable atopic asthmatic children and the control group. Both ascorbate and urate have been shown to be powerful antioxidants in plasma (25) and BAL fluid $(1,2)$. In humans a decrease in BAL fluid antioxidants has been shown in response to exposure to air pollutants such as ozone (26), nitrogen dioxide (1), and small particulates (27). Moreover, in guinea pigs the induction of an allergic pulmonary response leads to increased lipid peroxidation and decreased antioxidants $(\alpha-$ tocopherol, ascorbate, and thiols) in BAL fluid (28). Recently, decreased concentrations of ascorbate and $\alpha$-tocopherol and increased concentrations of urate have been shown after exercise in mild asthmatic adults $(9,29)$. The reason we did not find such a difference may be because our study group did not exercise before BAL and is much younger.

In nonasthmatic controls we have reported a weak but significant correlation between serum and BAL fluid concentrations of ascorbate, which has not been found in adults (30). As urate and ascorbate concentrations correlated strongly with protein concentrations in both groups of children, this suggests that ascorbate and urate diffuse along with protein into the epithelial lining fluid (2). However, in atopic asthmatic children we found no association between serum and BAL fluid concentrations of antioxidants. Two factors could account for this. First, in asthmatic children ascorbate in BAL fluid may have been consumed by oxidants. Second, as we did not find an overall decrease of ascorbate in BAL fluid, ascorbate might have been released from cells in the epithelial lining fluid. The problem with correction of BAL fluid measurements for a common denominator has been discussed controversially. In keeping with the recommendations of the European Respiratory Society Task Force on BAL, we present our data in concentrations per milliliter of recovered BAL fluid (31). Nevertheless, when corrected for total protein a trend toward decreased concentrations of ascorbic acid and uric acid in atopic asthmatic children was observed despite the fact that similar total protein concentrations were found in both groups, again indicating that antioxidant consumption may have been increased in the lungs of atopic asthmatic children.

We investigated the antioxidants ascorbate and urate, which are known to be among the most important water-soluble antioxidants in the epithelial lining fluid together with glutathione. Owing to their hydrophobic character they may have antioxidant function in the intra- and extracellular space. To evaluate an antioxidant-oxidant imbalance it would have been advantageous to determine the ratios between ascorbate and oxidized ascorbate (dehydroascorbate), and urate and one of its oxidation products, allantoin. However, both ascorbate and dehydroascorbate will be very rapidly oxidized. We therefore decided to reduce all ascorbate directly after sampling. Methodological difficulties in analyzing allantoin have resulted in a large number of methodological publications (32-34), none of which could be applied to our BAL samples.

Additionally we investigated the concentrations of two oxidation products (protein carbonyls for oxidation of proteins and MDAs for oxidative modification of lipids). Although no significant increase in the concentrations of oxidized proteins was observed in BAL fluid, there was a trend for higher concentrations in protein carbonyls in atopic asthmatic children compared with controls. This is in agreement with Foreman et al. (35), who have shown increased numbers of protein carbonyls in BAL proteins of atopic asthmatic adults $18 \mathrm{~h}$ after allergen challenge. Additionally, in a small subgroup of our atopic asthmatic and control children we measured the concentrations of MDA, a marker of lipid peroxidation. Both markers of oxidative stress (protein carbonyls and MDA) correlate strongly with each other in atopic asthmatic children, suggesting that oxidative stress occurs simultaneously in both proteins and lipids.

The numbers of inflammatory cells are weakly correlated with the concentration of oxidized protein in all children (data not shown). When analyzing atopic, asthmatic and control children separately, these correlations are much stronger in atopic asthmatic children. Furthermore, in atopic asthmatic children, macrophage, eosinophil, and mast cell numbers are significantly correlated with the concentration of oxidized proteins. Interestingly, there was no significant association between these inflammatory cells and oxidatively modified proteins in control children, suggesting that these cells may not play a role in oxidative damage to proteins in noninflammatory conditions. In asthma, however, eosinophils contribute to oxidative modification of proteins after allergen challenge (35) and also during symptom-free periods. This is supported by our finding that, when applying our previously published upper $95 \%$ confidence limit of the 95th centile of our normal population (24) $\left(\geq 0.86 \%\right.$ or $\left.\geq 0.039 \times 10^{5} / \mathrm{mL}\right)$ as the cutoff value for eosinophilic inflammation, protein carbonyls were significantly increased in atopic asthmatic children. Others have measured brominated or chlorinated proteins (tyrosines) as a marker of oxidative damage by eosinophils and neutrophils $(36,37)$. Although determination of those specific oxidation markers would identify more precisely the source of oxidative modification, in our group of atopic asthmatic children only eosinophils and mast cells were significantly increased in BAL fluid compared with control children, in line with our previous observations (17).

Surprisingly, analyzing the group of atopic asthmatic children separately according to their asthma treatment [parental report of the use of ICS (and bronchodilators when needed) or use of $\beta_{2}$-adrenergic agonists only] revealed no differences in total protein, any of the antioxidants, or protein carbonyls between the two groups. A possible explanation could be that the distribution and absorption of inhaled drugs in the lungs of children may differ from those of adult patients. Apart from the parents' report we do not have any measure of how often and how much of the prescribed drugs have been used. 
The lipid-soluble micronutrient antioxidants $\alpha$-tocopherol, retinol, $\alpha$ - and $\beta$-carotene, and lycopene, as well as uric acid and ascorbic acid, were determined in serum. No statistical differences were found in ascorbate, urate, $\alpha$-tocopherol, retinol, $\beta$-carotene, and lycopene concentrations in this study between the groups. Only one older study by Olusi et al. (38) found significantly decreased ascorbic acid in the plasma of children with asthma. More recently in children with exerciseinduced bronchoconstriction, an association between resting forced expiratory volume in $1 \mathrm{~s}$ and serum $\alpha$-tocopherol concentrations was reported in boys and between forced expiratory volume in $1 \mathrm{~s}$ and retinol concentrations in girls (39). Atopic asthmatic children in this study had significantly lower serum concentrations of $\alpha$-carotene than controls. Carotenoids have antioxidant activity, suggesting that they might be reduced in plasma by increased oxidative stress. However, the dietary intake of fresh fruit and vegetables was not determined in this study. Although a lower intake of vitamins in atopic asthmatic children cannot be excluded, an exclusive lower intake of carotenoids is unlikely, as the serum concentrations of the other vitamins were similar between groups.

\section{CONCLUSIONS}

In summary, overall the BAL antioxidant concentrations investigated in this study did not differ between currently healthy atopic asthmatic children and control children. A previously described association between serum and BAL fluid ascorbate in nonasthmatic children was not found in asthmatic children, which may suggest a higher consumption by oxidants in some children. However, increased BAL eosinophils indicate ongoing airway inflammation, which may increase oxidatively modified proteins as reflected by increased protein carbonyl concentrations in our group of children with elevated numbers of eosinophils in BAL fluid.

\section{REFERENCES}

1. Kelly FJ, Mudway I, Krishna MT, Holgate ST 1995 The free radical basis of air pollution: focus on ozone. Respir Med 89:647-656

2. Cross CE, Van der Vliet A, O’Neill C, Louie S, Halliwell B 1994 Oxidants, antioxidants, and respiratory tract lining fluids. Environ Health Perspect 102(suppl 10): 185-191

3. Schwartz J, Weiss ST 1994 Relationship between dietary vitamin C intake and pulmonary function in the First National Health and Nutrition Examination Survey (NHANES I). Am J Clin Nutr 59:110-114

4. Cohen HA, Neuman I, Nahum H 1997 Blocking effect of vitamin C in exerciseinduced asthma. Arch Pediatr Adolesc Med 151:367-370

5. Grievink L, Jansen SMA, Van't Veer P, Brunekreef B 1998 Acute effects of ozone on pulmonary function of cyclists receiving antioxidant supplementation. Occup Environ Med 55:13-17

6. Britton JR, Pavord ID, Richards KA, Knox AJ, Wisniewski F, Lewis SA, Teatterfield AE, Weiss ST 1995 Dietary antioxidant vitamin intake and lung function in the general population. Am J Respir Crit Care Med 151:1383-1387

7. Strachan D, Cox BD, Erzinclioglu SW, Walters DE, Whichelow MJ 1991 Ventilatory function and fresh fruit consumption in a random sample of British adults. Thorax 46:624-629

8. Kelly FJ, Blomberg A, Drew AJ, Holgate ST, Sandström T 1996 Antioxidant kinetics in lung lining fluid following exposure of humans to nitrogen dioxide. Am J Respir Crit Care Med 152:1700-1705

9. Kelly FJ, Mudway I, Blomberg A, Frew A, Sandström T 1999 Altered lung antioxidant status in patients with mild asthma. Lancet 354:482-483

10. Vachier I, Damon M, Le Doucen C, Crastes de Paulet A, Chanez P, Michel FB, Godard P 1992 Increased oxygen species generation in blood monocytes of asthmatic patients. Am Rev Respir Dis 146:1161-1166

11. Chanez P, Dent D, Yukawa T, Barnes PJ, Chung KF 1990 Generation of oxygen free radicals from blood eosinophils from patients after stimulation with PAF or phorbol ester. Eur Respir J 3:1002-1007
12. Cluzel M, Damon M, Chanez P, Bousquet J, Crastes de Paulet A, Michel FB, Godard P 1987 Enhanced alveolar cell luminol-dependent chemiluminescence in asthma. J Allergy Clin Immunol 80:195-201

13. Magori M, Vachier I, Godard P, Force M, Bousquet J, Chanez P 1998 Superoxide anion production by monocytes of corticosteroid-treated asthmatic patients. Eur Respir J 11:133-138

14. Warner JO 1992 Asthma: a follow up statement from an international paediatric asthma consensus group. Arch Dis Child 67:240-248

15. Ennis M, Shields MD 1997 Childhood asthma: an inflammatory disease? J Physiol Pharmacol 48(suppl 2):43-49

16. Schock BC, Young IS, Brown V, Fitch PS, Taylor R, Shields MD, Ennis M 2001 Antioxidants and protein carbonyls in bronchoalveolar lavage fluid of children: normal data. Pediatr Res 49:155-161

17. Stevenson EC, Turner G, Heaney LG, Schock BC, Taylor R, Gallagher T, Ennis M, Shields MD 1997 Bronchoalveolar lavage findings suggest two different forms of childhood asthma. Clin Exp Allergy 27:1027-1035

18. Heaney LG, Stevenson EC, Turner G, Cadden IS, Taylor R, Shields MD, Ennis M 1996 Investigating paediatric airways by non-bronchoscopic lavage: normal cellular data. Clin Exp Allergy 26:799-806

19. Chevion S, Berry EM, Kitrossky N, Kohen R 1997 Evaluation of plasma low molecular weight antioxidant capacity by cyclic voltammetry. Free Radic Biol Med 22:411-421

20. Ikenoya S, Abe K, Tsuda T, Yamano Y, Hiroshima O, Ohmae M, Kawabe K 1979 Electrochemical detector for high-performance liquid chromatography. II. Determination of tocopherols, ubiquinones and phylloquinone in blood. Chem Pharm Bull 27:1237-1244

21. Ito Y, Ochiai J, Sasaki R, Suzuki S, Kusuhara Y, Morimitsu Y, Otani M, Aoki K 1990 Serum concentrations of carotenoids, retinol, and $\alpha$-tocopherol in healthy persons determined by high-performance liquid chromatography. Clin Chim Acta 194:131144

22. Buss H, Chan TP, Sluis KB, Domigan NM, Winterbourn CC 1997 Protein carbonyl measurement by a sensitive ELISA method. Free Radic Biol Med 23:361-366

23. Young IS, Trimble ER 1991 Measurement of malondialdehyde in plasma by high performance liquid chromatography with fluorimetric detection. Ann Clin Biochem 28:504-508

24. Shields MD, Brown V, Stevenson EC, Fitch PS, Schock BC, Turner G, Ennis M 1999 Serum eosinophilic cationic protein and blood eosinophil counts for the prediction of the presence of airways inflammation in children with wheezing. Clin Exp Allergy 29:1382-1389

25. Nyyssönen K, Porkkala-Sarataho E, Kaikkonen J, Salonen JT 1997 Ascorbate and urate are the strongest determinants of plasma antioxidative capacity and serum lipid resistance to oxidation in Finnish men. Atherosclerosis 130:223-233

26. Mudway IS, Housley D, Eccles R, Richards RJ, Datta AK, Tetley TD, Kelly FJ 1996 Differential depletion of human respiratory tract antioxidants in response to ozone challenge. Free Radic Res 25:499-513

27. Schock B, Young IS, Fitch P, Brown V, Taylor R, Shields MD, Ennis M 1998 The effect of glass fronted fires on antioxidants in serum and BAL fluid from children. Pediatr Res 44:45(abstr)

28. Shvedova AA, Kisin ER, Kagan VE, Karol MH 1995 Increased lipid peroxidation and decreased antioxidants in lungs of guinea pigs following an allergic pulmonary response. Toxicol Appl Pharmacol 132:72-81

29. Mudway I, Stenfors N, Blomberg A, Dunster C, Frew A, Holgate S, Sandström T, Kelly FJ 1997 Compromised pulmonary epithelial lining fluid (ELF) antioxidant status in mild asthmatic subjects. Eur Respir J 10(suppl 25):265s(abstr)

30. Van der Vliet A, O’Neill CA, Cross CE, Koostra JM, Volz WG, Halliwell B, Louie S 1999 Determination of low-molecular-mass antioxidant concentrations in human respiratory tract lining fluids. Am J Physiol 276:L289-L296

31. de Blic J, Midulla F, Barbato A, Clement A, Dab I, Eber E, Green C, Grigg J, Kotecha S, Kurland G, Pohunek P, Ratjen F, Rossi G 2000 Bronchoalveolar lavage in children. ERS Task Force on bronchoalveolar lavage in children. European Respiratory Society. Eur Respir J 15:217-231

32. Marklund N, Ostman B, Nalmo L, Persson L, Hillered L 2000 Hypoxanthine, uric acid and allantoin as indicators of in vivo free radical reactions: description of a HPLC method and human brain microdialysis data. Acta Neurochir (Wien) 142:1135-1141

33. Lagendijk J, Ubbink JB, Vermaak WJ 1995 The determination of allantoin, a possible indicator of oxidant status, in human plasma. J Chromatogr Sci 33:186-193

34. Kock R, Devoux B, Greiling H 1993 A high-performance liquid chromatographic method for the determination of hypoxanthine, xanthine, uric acid and allantoin in serum. Eur J Clin Chem Clin Biochem 31:303-310

35. Foreman R, Mercer P, Kroegel C, Warner J 1999 Role of the eosinophil in protein oxidation in asthma: possible effects on proteinase/antiproteinase balance. Int Arch Allergy Immunol 118:183-186

36. Wu W, Samoszuk MK, Comhair SAA, Thomassen MJ, Farver CF, Dweik RA, Kavuru MS, Erzurum SC, Hazen SL 2000 Eosinophils generate brominating oxidants in allergen-induced asthma. J Clin Invest 105:1455-1463

37. Senthilmohan R, Mocatta T, Buss H, Darlow B, Wagner J, Kettle A, Winterbourn C 2001 Oxidative modification of proteins in cystic fibrosis patients and in chronic lung disease of premature infants. Free Radic Biol Med 31(suppl 1):S89 (abstr)

38. Olusi SO, Ojutiku OO, Jessop WJE, Iboko MI 1979 Plasma and white blood cell ascorbic acid concentrations in patients with bronchial asthma. Clin Chem Acta 92:161-166

39. Kelly YJ, Brabin BJ 1997 Do antioxidants matter for asthmatics? Clin Asthma Rev $1: 145-152$ 